\title{
Ioan Dănilă, Limba română în graiul ceangăilor din Moldova, Editura Didactică și Pedagogică, București, 2005, 354 p.
}

\author{
Enikő Pál* \\ Faculty of Economics, Socio-Human Sciences and Engineering, Sapientia University, Piața Libertății 1, 530104 Miercurea Ciuc, Romania
}

Theoretically, language speakers are aware of the fact that their individual speech acts belong to a hierarchically superior language system which exceeds their own idiolect and, in case they use a local dialect, they are able to integrate the particular dialect into a national and/or historic language, mostly without much difficulty. For instance, even if a speaker from Oltenia would claim that he speaks "Oltenian", by which he differentiates himself from other speakers of the same language, he most certainly would recognize that the "language" he speaks is Romanian. Likewise, no speaker of the Szekler dialect would question the fact that he speaks Hungarian, more precisely one of its dialects, even though he consciously distances himself from the other speakers of the same language. However, linguistic consciousness does not always manifest itself so clearly distinguishable. Speakers' awareness of linguistic affiliation may present fluctuations especially if their belonging to an ethnic group is perceived to be conflicted ${ }^{1}$. In this sense, an eloquent example is that of the Csángó communities. Certain surveys (see Pávai, 1995/1999; Tánczos, 2011; Péntek, 2013) show, for instance, that there are situations in which the Csángó speaker faces a dilemma when he is asked what language he speaks, although his hesitancy (in choosing between Hungarian - Romanian - or even "Csángó" language) does not always reflect his indecision regarding his self-definition, but it is often due to the perception of a conflicted state between his self-image and the externally instilled image, whether internalized or not. On the other hand, on individual or community level and depending on the wider historical, geopolitical or communicational context, some of the Csángós implicitly or expressly declare themselves to be speakers of Romanian language, others claim to be Hungarian language speakers and they do it so either intuitively or based on certain pre-concepts.

The dilemmatic, even "problematic" status of this ethnic and linguistic community-regarded as "one of Europe's most enigmatic and least known ethnic minorities" (Baker, 1997, p. 658)—also prevails in the scientific research on Csángós. The plethora of theories concerning their origin, the diversity of perspectives adopted in discussing the "Csángó ethno-linguistic phenomenon" (Ichim \& Ichim, 2002, p. 156), the numerous controversies and contradictions regarding the nature of this particular form of Romanian-Hungarian bilingualism are indicative of the difficulty in unravelling this issue which thus seems to be lost in the mists of uncertainty, in which the ethnic and linguistic affiliation remains an almost unsolvable problem or, in any event, an "insufficiently clarified" (Sala, 2001, s.v. ceangău) matter. The unequivocal findings concern only the Roman Catholic religion and the mainly bilingual nature of the Csángós who incorporate into their language Romanian and Hungarian elements to an extent scarcely equalled in any other dialects. However, both the Romanian components, on the one hand, and the Hungarian components, on the other hand, have been relatively briefly and only partially discussed so far, they not being identified beyond dispute nor exploited well enough and in all their complexity yet. In this regard, the book entitled Limba română în graiul ceangăilor din Moldova [Romanian language in the Moldavian Csángó dialect], signed by Ioan Dănilă and published by Editura Didactică și Pedagogică - R.A. of Bucharest in 2005, provides edifying clarifications of the subject matter.

\footnotetext{
*Email address: enikopaldr@gmail.com.

${ }^{1}$ As a matter of fact, the very concept of 'identity' implies mobility according to the social and cultural circumstances which generated it since identity may be viewed as an adaptive mechanism that enables groups of individuals to adjust to different situations. In case a community defines itself by a bicultural identity which combines a "familial identity" with a "target cultural identity", oriented towards a desired model, linguistic consciousness, in its turn, may appear to be confusing, or at any rate, expressing certain limits.
} 
The study of the professor from Bacău did not go unnoticed at the time it was published either, but it justly aroused interest, several meritorious reviews being dedicated to it. Nevertheless, we believe that its resources have not yet been exhausted, and that it is fully worth our attention due to the essential contributions, rectifications, and improvements it brings to the research on Moldavian Csángó dialect.

Although specialists have paid close attention to the Csángó issue for a long time, the first studies dating back early in the $19^{\text {th }}$ century, the number of papers on this topic growing exponentially afterwards especially in the second half of the $20^{\text {th }}$ century $^{2}$, by the end of the century making its way into scientific debate held on different events-such as national symposiums or international seminars-, the results of the research conducted on these occasions are often contradictory and incomplete in many respects.

For instance, many of the studies dedicated to Csángós focus rather on the ethnic and socio-cultural status of this community, providing mostly ethnographic descriptions ${ }^{3}$, and only a few of them deal with linguistic issues. Although purely linguistic studies are not completely absent from literature either ${ }^{4}$, their number is relatively small, at least compared to those dealing with identity issues. Linguistic remarks on the Csángó dialect are to be found rather sporadically and they usually sum up a series of phonetic and lexical features, observed during fieldwork and presented in the form of lists, sometimes without comments or accompanied by brief explanations. Thus, linguistic studies most often emphasized certain representative features, such as the sibilant pronunciation characteristic for Csángó people ${ }^{5}$, or they took into account various loanwords from Romanian language (Márton, 1972) ${ }^{6}$ or the Hungarian lexical stratum (Szabó, 1959; see also Péntek, 2006).

On the other hand, another shortcoming of the previous researches is the fact that, despite they encompass valuable fieldwork, their results have not been published in a distinct corpus, but they were often included in the general lexical inventory of Romanian and/or Hungarian language, within its regional varieties. A linguistic atlas of Moldavian Csángó dialect, prepared by Murádin László and Péntek János, edited by Gálffy Mózes, Márton Gyula and Szabó T. Attila, was published only in 1991, at Budapest, in Hungarian, entitled $A$ moldvai csángó nyelvjárás atlasza, I-II [Atlas of Moldavian Csángó Dialect]. In fact, this was preceded by a dictionary of the Northern Csángó dialect, published in 1936, in Helsinki (cf. Márton, 1973, p. 177), but it was probably less known among Hungarian and/or Romanian researchers.

Last but not least, the study of the Romanian component of the Csángó dialect has been somewhat neglected. Although specialists drew attention to the fact that Csángó dialect represents a peculiar form of bilingualism which "requires a careful study of both languages spoken by [this] population" (Mărtinaş, 1985, p. 9), the previous researches almost exclusively, or at any rate, mainly focused on the Hungarian elements-as the author of the present book repeatedly notes (p. 6, 39, 40, 46) 7 . Yet the uniqueness of the Csángó dialect is given precisely by the specific manner in which it relates to Romanian language, on the one hand, and to Hungarian language, on the other hand, its relations to these two languages being variable in time and space.

Thus, despite all the progress made in previous

\footnotetext{
${ }^{2}$ For lists of references regarding Csángó research see Ilyés et al. (2006); see also Gergely et al. (2010, p. 91-92); see also KJNT (online source). As a matter of fact, the Csángó issue seems to have established a whole new and almost autonomous "science" with an epistemological system of its own, quite often doctrinaire and ideologized, and with a frequently mythologized specialized language.

${ }^{3}$ Indicative of this fact are not only the individual works of different specialists-among which we could mention the contributions of Pozsony (2002) - , but also the volumes of selected studies (see Pozsony, 1999), some of them designed in the form of an electronic database (see KINDA-PETI), as well as certain regular or occasional rubrics dedicated to national minorities, in general, or to Csángó people, in particular, such as the rubric called Kelet Népe [People of the East] in the journal named „Székelyföld” [Szeklerland].

${ }^{4}$ For Hungarian research see Szabó (1959), Márton (1973) and Tánczos (2004), whereas for Romanian linguistic researches see Benő \& Murádin (2002).

${ }^{5}$ A more detailed description of this particular phenomenon was written by Mircea Borcilă (1965), his findings being resumed and nuanced afterwards by Dumitru Mărtinaș (1985).

${ }^{6}$ In certain cases, the term loanword may be inappropriate since some of the words may be regarded simply as the result of crosslinguistic influence of Romanian and Hungarian languages and, thus, the legitimacy of borrowing is quite vulnerable.

7 This fact may be explained by a certain political context, which-especially during the 1950s and 1960s-oriented researches towards the Hungarian component of Csángó bilingualism.
} 
researches, only few of the studies aimed solely and entirely at the Csángó dialect, valorizing the contribution of both languages which gives the specific nature of this Romanian-Hungarian idiom. In this regard, the book written by Ioan Dănilă represents the first actual synthesis of this particular issue. By adopting a holistic approach, meant to fill the gaps left behind in previous studies, this book constitutes a reference work of Csángó dialect research.

The subject matter of the present work is structured into three main sections: I. Introducere [Introduction], II. Bilingvismul - concept, variante terminologice, concretizări [Bilingualism - concept, terminology, applications] and III. Limba română în graiul ceangăilor din Moldova [Romanian language in the Moldavian Csángó dialect], followed by two pages dedicated to Conclusions, an extensive thematic Bibliography, which lists the important studies on this topic, and by Annexes ${ }^{8}$. The clear and systematic ordering of the ideas within each section and their logical and natural sequence from one section to the other makes it easier to traverse the arduous path which crosses the here and there slippery and obscure field of Csángó dialect.

In the section entitled Introducere [Introduction], the author outlines the main problems which Csángó dialect research has to face and he also delineates the geographical distribution of this population. It is pointed out that Csángó people represent a linguistic community that lacks territorial homogeneity since they are dispersed over a wide area along the Siret River Valley, "in its middle basin, with the landmarks of Paşcani city, in the North, and the confluence of Trotuş and Siret, in the South" (p. 5), also having certain ramifications towards the Eastern regions (Iaşi county) and Western areas (Neamț and Vrancea counties). It is also indicated that within this population there can be distinguished two main groups: on the one hand, its Northern (city of
Roman) and Southern (Bacău county) ramifications and, on the other hand, the communities in the Trotuş and Tazlău region, these two categories of speakers being well aware of the differences in their dialect and traditions, "which makes any kind of confusion to be rebuked" (p. 5). The author also draws attention to the fact that all studies on Csángó dialect should take into account two aspects: its relation to Romanian language and to Hungarian language respectively, "as a consequence of the phenomenon of Szeklerization” (p. 5). Acknowledging the fact that "the issue of Romanian language in Csángó dialect is extremely complicated and, as such, delicate" (p. 5), the author intends to demonstrate, based on a dialectal study, the viability of Romanian lexical elements in the Moldavian Csángó dialect (p.6).

In the second section, the author begins with interpreting different definitions given to the phenomenon of bilingualism, listing its terminological variants too. Taking the Chomskyan interpretation as his theoretical framework, according to which real bilingualism is validated by the linguistic competence and performance of speakers while using both languages in contact, the author's argumentation aims at defining Csángó dialect as one of the specific forms of "dialectal bilingualism" which is "characterized by the individuals' ability to use with the same level of performance two different linguistic codes" (p. 9). The chapter entitled Româna și maghiara, limbi in contact [Romanian and Hungarian, two languages in contact] appears us to be of great importance. Here the author briefly and critically presents the main studies dealing with Hungarian influence on Romanian language, on the one hand, and the researches concerning Romanian influence on Hungarian language, on the other hand, also pointing out the shortcomings and inconsistencies found in the approaches to one or the other of the analysed aspects.

\footnotetext{
${ }^{8}$ This section contains the following annexes: Tablou de corespondență NALR-MCNA [Table of correspondences between NALR and MCNA] (Annex no. 1), which lists, in alphabetical order, the words mapped either on Noul atlas lingvistic român [New linguistic atlas of Romanian language] (NALR), or on A moldvai csángó nyelvjárás atlasza [Atlas of Moldavian Csángó dialect] (MCNA) or on both of them; Lista localităților anchetate [List of the surveyed settlements] (Annex no. 2A), also mentioning the cartographic number of these settlements in MCNA and offering data regarding their presence or absence in NALR or in other linguistic atlases; Indice de cuvinte-titlu [Index of entry words] (Annex no. 2B), which contains 359 units, grouped in 14 onomasiological fields, as follows: house, transport / administration, school, human body, family / health, different conditions, footwear / clothing, nutrition, emotions / features, agriculture, the sky, the woods, wild animals and time; Inventar lexical [Lexical inventory] (Annex no. 2C), in which Romanian words are accompanied by their Hungarian correspondents and phonetic variants; and, finally, Hărți dialectale [Dialectal maps] (Annex no. 2D), designed based on the lexical inventory.
} 
The most voluminous and essential section is the third chapter which begins with the history of the word ceangău 'Csángó' (p. 19-26). The monographic description of this word not only offers important data regarding its etymology, attestations, meanings and usage in different domains, but it also allows to draw some extremely interesting conclusions about the itinerary this lexeme went through. Thus, for instance, the author points out that the different descriptions show a "pseudo-semantization" of the term ceangăi 'Csángós, " "process generated by the double decoding and fluctuations in lexicographers' definitions" (p. 24). Furthermore, the author observes that this term is not only an ethnonym, but it also has become a cognomen, as the Csángós themselves perceive it (p. 25). The pejorative reflexes of the term, however, could not eliminate this "label" applied to a clearly distinct reality, which is why the appellative ceangău 'Csángó, deeply rooted in the common mentality, is preserved despite the necessity of a semantic clarification.

Subsequently, the author dedicates a few pages (p. 26-35) to the issue of sibilant pronunciation which represents the major phonetic peculiarity of Moldavian Csángó dialect. The author's main contribution regarding this problem consists of the fact that he offers a detailed overview of this particular phenomenon. It begins with a few terminological considerations, among which he notes, for instance, the inconsistency and inadequacy of Romanian linguistics' terminology regarding the description of the sibilant consonants. Then the author reviews the main references to this phenomenon in literature, which is followed by a detailed description of the sibilant pronunciation, also accounting its origin and distribution respectively. As a matter of fact, the status of "insular dialect" (p.33) of the Csángó idiom is given precisely by its phonetic particularities, by which it distinguishes itself both from Romanian and Hungarian languages.

In what follows, the Moldavian Csángó dialect is discussed from the perspective of both its Hungarian component (p. 43-47, 63-81) and its Romanian component (p. 40-43, 81-91). First the author makes some theoretical and practical comments on the notions 'linguistic community' and 'linguistic awareness', showing that, in fact, Moldavian Csángó people do not consider themselves as either a linguistic nor an ethnic community, but rather a religious one (p. 36). Then the author's attention turns to the way in which Moldavian Csángós relate to Romanian and Hungarian languages. Discussing certain opinions found in previous studies on Csángó dialect's Romanian and Hungarian components, the author recommends "caution when intending to catalogue Csángó dialect in a certain way or another" (p. 45). This imperative appears to be fully justified in the chapter entitled Stadiul cercetärilor privind graiul ceangăilor din Moldova [Current state of research on Moldavian Csángó dialect] (p. 47-62). At the end of this section the reader may reach the conclusion that the linguistic reality recorded by researchers is constantly changing which leads to certain doubts regarding the validity of the presented data. As a matter of fact, the majority of the inconsistencies found in the studies on this topic derive from the divergence of premises. Thus, in many cases, the studies' main purpose is either to confirm the Hungarian origin of the Csángó communities ("Romanianized Hungarians") or, on the contrary, to reunite and tighten the strong relations between Transylvanian and Moldavian Romanian dialects and the dialect spoken by Csángó people ("Magyarized Romanians", this time). In the first case, Csángó dialect is consequently treated from the perspective of "Romanian influence" and "Romanian loanwords". In the second case, studies show the gradual regression of "Hungarian influence" on the Csángó dialect. Notwithstanding the problems regarding the clarification of the Csángós' origin, in reality, the difficulty in cataloguing in a way or another the recorded linguistic phenomena is due, in our opinion, to the advanced stage of the Csángós' bilingualism and to the inner mechanisms of this phenomenon, to the variable tendencies towards linguistic dominance? ${ }^{9}$. For instance, in case of a loanword of Hungarian origin which was naturalized

\footnotetext{
${ }^{9}$ The fact that Csángó dialect represents an advanced stage of bilingualism may be sustained by the great number of synonymic pairs formed by a Romanian and a Hungarian word respectively, these pairs being more frequent than those including two Romanian or two Hungarian words. Another argument in favour of the advanced bilingualism is the phenomenon of word contamination in which case Romanian and Hungarian elements are brought together to form one linguistic unit (a lexeme or phrase). On the other hand, the variability of Romanian or Hungarian dominance over the interconnected systems within the Csángó dialect is also governed by certain extra linguistic factors, such as the geographic location of different communities or the given historic epoch. What is more, the relatively homogeneous groups of speakers are not entirely compact either.
} 
and widespread in all Romanian dialects and vice versa, it is quite difficult to determine from which language the given word had entered into the Csángó dialect since, at least theoretically, there are two possibilities for each case, both plausible, not to mention the process of re-borrowing. For example, in the Csángó dialect the word biruje 'to govern, to dominate', which is a quite early Hungarian loanword of the Romanian language (< Hung. birni 'id.'), may be explained either from Hungarian or Romanian language ${ }^{10}$, unless the phenomenon of borrowing does not overlap with that of bilingualism.

Continuing the discussion of the linguistic studies written on Moldavian Csángó dialect, the author allocates a few pages to dialectal studies as well and dedicates a separate chapter (p. 73-81) to the atlas of the Moldavian Csángó dialect, published in 1991 in Budapest. This precedes the presentation of the dialectal research carried out by the author himself and serves as a premise to justify the necessity of undertaking such an endeavour. The author acknowledges the merits of this "reference work in Romanian and Hungarian linguistics" (p. 75) and praises the effort of the Hungarian team who gathered the data for it but he also shows a few of its shortcomings. Thus, summarizing the content of the Atlas of Moldavian Csángó Dialect (1991), the author shows that it lists only the Hungarian component of the dialect. This fact encourages him to carry out a dialectal research which assumes the role of legitimating the Romanian component, an endeavour undertaken for the first time in Romanian linguistics.

Noticing that the dialect of Moldavian bilingual Csángós has never been the subject of thorough studies in Romanian dialectology, which determined researchers to systematically avoid the issue of Csángó dialect even when discussing Moldavian dialects (p. 39), the professor from Bacău aims to fill this gap. Thus, he engages himself into a fieldwork in order to design a lexical corpus which reflects the
Csángó dialect of 29 settlements where "Hungarian language is still spoken" (p. 87) and where the dialectal bilingualism is to be found. The main purpose of the research was to map the Romanian component of the Moldavian Csángó dialect. The results of the linguistic survey, which has been carried out respecting the rigorous methodology of linguistic geography, are presented in the form of a lexical inventory (Annex no. 2C), based on which the dialectal maps (Annex no. 2D) have been designed. This section represents a substantial contribution of the author to the topic in question. As a matter of fact, the 359 dialectal maps occupy a considerable space within the work representing almost half of it. The unitary image offered by the author regarding the strictly lexical linguistic reality unequivocally demonstrates the oldness, consistency and viability of the Romanian component of the Moldavian Csángó dialect.

The study of the professor from Bacău is more than welcome ten year after its publishing too and it most certainly will last in the future as well, due to its numerous merits ${ }^{11}$. Thus, it is remarkable, among other things, for the judicious combining of the synchronic, diachronic and comparative approaches by means of which it offers a wider view of Moldavian Csángó dialect, open to further research, since "the linguistic data collected during the dialectal survey ought to be interpreted, in later stages, from the perspective of its phonetic [...], lexical [...] and grammatical properties" (p. 92). On the one hand, the pages of the volume display an extremely rigorous scientific endeavour, based on a thorough knowledge of literature, employed critically, and on the deep understanding of the studied spoken dialect. On the other hand, the massive dialectological study on the lexical properties of the researched area grants the book a special place among the researches on this particular dialect, since its findings and data may

\footnotetext{
${ }^{10}$ The authors of a dialectal survey made for the Atlas of Hungarian Dialects list it among the loanwords of Romanian origin in the Csángó dialect and the author of the present book considers "the hypothesis of the term's conservation from Romanian language and its adaptation, in contact with Hungarian language, to its morphological system” to be more plausible (p. 47-48).

${ }^{11}$ If there were anything to be reproached to the present book, that would concern not its content, but its small typos or drafting errors which are insignificant really. We shall note, however, the less fortunate choice of the example given by the author to show the existence of vowel harmony in Hungarian language. Thus the Accusative form of the word Hung. ember 'person, human being, man' is not ember-et (p. 43) but embert, since, in this case, the Accusative affix is attached directly to the root without the necessity of introducing an auxiliary vowel (cf. Hung. ház-at 'house (Ac.)', the other example given by the author). In this regard, if he was to keep the very example, a more illustrative form of the word would have been its plural, see Hung. ember-ek, because in this form the plural affix $-k$ is indeed attached to the root with an auxiliary vowel selected by vowel harmony (cf. also Hung. ház-ak 'houses').
} 
represent the support of an augmented and nuanced linguistic atlas of the Moldavian Csángós.

By means of these qualities, the book entitled Limba română în graiul ceangăilor din Moldova [Romanian language in the Moldavian Csángó dialect] constitutes a work of authority in Romanian linguistics and a leading study on Romanian-Hungarian bilingualism, in general, and on Csángó dialect, in particular. The paper of professor Ioan Dănilă makes an important step to dispel the confusion-often due to mystification-around this linguistic community, frequently treated as an enigmatic one, and to clarify the peculiarities of this "linguistic island", placing the study of Moldavian Csángó dialect in the right course of modern linguistic research.

\section{References}

Baker, R. (1997). On the origin of the Moldavian Csángós, in “The Slavonic and East European Review” 75, p. 658-680.

Benő, A. \& Murádin, L. (2002). Csángó Dialect - Csángó Origins, in Diószegi, L. (ed.), Hungarian Csángós in Moldavia. Essays on the Past and Present of the Hungarian Csángós in Moldavia, Teleki László Foundation - Pro Minoritate Foundation, Budapest, p. 163175.

Borcilă, M. (1965). Un fenomen fonetic dialectal: rostirea lui ş ca sși $\boldsymbol{j}$ ca $\boldsymbol{z}$ în graiurile dacoromâne. Vechimea și originea fenomenului, in "Studia Universitatis Babeș-Bolyai", Series Philologia, Fasciculus 2, p. 109-121.

Gergely, A. et al. (ed.) (2010). Antropológiai - etnológiai - kultúratudományi kislexikon, $2^{\text {nd }}$ edition, MTA PTI Etnoregionális és Antropológiai Kutatóközpont, Budapest.

Ichim, Fl. \& Ichim, D. (2002). Catolicii moldoveni, Editura „Diagonal”, Bacău.

Ilyés, S., Pozsony, F. \& Tánczos, V. (2006). A moldvai csángók bibliográfiája, Kriza János Néprajzi Társaság, Kolozsvár.

KINDA-PETI = Kinda, I. \& Peti, L. (eds). A moldvai csángók, Erdélyi Magyar Adatbank, [online].

KJNT = KJNT Csángó Bibliográfiája (1988-2011), [online].

Mărtinaș, D. (1985). Originea ceangăilor din Moldova, Editura Științifică și Enciclopedică, București.

Márton, Gy. (1972). A moldvai csángó nyelvjárás román kölcsönszavai, Kriterion, Bukarest.

Márton, Gy. (1973). A romániai magyar nyelvjáráskutatás múltja és mai állása, Korunk Évkönyv, Tanulmányok a romániai magyar tudományosság műhelyéből, Kolozsvár, p. 173-193.

Pávai, I. (1995/1999). A moldvai magyarok megnevezései, in "Regio. Kisebbségi Szemle” 6, Budapest, Teleki László Alapítvány, 1995, nr. 4, p. 149-164 (republished under the title Etnonimek a moldvai magyar anyanyelvü katolikusok megnevezésére, in Pozsony, 1999, p. 69-82).

Péntek, J. (2006). A belsö tagolódás kérdése a moldvai magyarban a szóföldrajz alapján, in "Nyelv-és Irodalomtudományi Közlemények" L, 1-2, p. 29-52.

Péntek, J. (2013). Mi lesz itten velünk, ezekvel a magyarokval? (A moldvai magyarok nyelvi önképe az elözö század ötvenes éveiböl), in "Székelyföld", XVII/9, p. 155-170.

Pozsony, F. (ed.) (1999). Csángósors. Moldvai csángók a változó időkben, A Magyarságkutatás Könyvtára XXIII, Teleki László Alapítvány, Budapest.

Pozsony, F. (2002). Ceangăii din Moldova, Asociația Etnografică Kriza János, Cluj-Napoca.

Sala, M. (coord.) (2001). Enciclopedia limbii române, Editura "Univers Enciclopedic", București.

Szabó, T. Attila (1959). A moldvai csángó nyelvjárás kutatása, in “Magyar Nyelvjárások” V, Budapest, p. 3-41.

Tánczos, V. (2004). A moldvai csángók nyelvészeti kutatása (1945-2004), in Kiss, J. (ed.), Nyelv és nyelvhasználat a moldvai csángók körében, A Magyar Nyelvtudományi Társaság Kiadványai 221., Budapest, p. 208-285.

Tánczos, V. (2011). A moldvai csángók magyar nyelvismerete 2008-2010-ben I-III, in "Székelyföld” XV/5, p. 90-117; XV/6, p. 102$131 ; \mathrm{XV} / 7$, p. $104-138$. 